\title{
1 Aqueous chemistry of Ce(IV): estimations using actinide analogues
}

2

3 Rémi Marsac ${ }^{\mathrm{a} *}$, Florent Réal $^{\mathrm{b}}$, Nidhu Lal Banik ${ }^{\mathrm{c}}$, Mathieu Pédrot ${ }^{\mathrm{a}}$, Olivier Pourret ${ }^{\mathrm{d}}$, Valérie 4

5

6

$7 \quad{ }^{a}$ Géosciences Rennes UMR 6118, Université Rennes 1, CNRS, 35042 Rennes cedex, France

8 b Univ. Lille, CNRS, UMR 8523 - PhLAM - Physique des Lasers Atomes et Molécules, F-59000

9 Lille, France

$10{ }^{c}$ JRC-KARLSRUHE, G.II.6 - Nuclear Safeguards and Forensics, European Commission, P.O.Box 11 2340, D-76125 Karlsruhe, Germany

$12 \quad{ }^{\mathrm{d}}$ HydrISE, UniLaSalle, 60026 Beauvais cedex, France

13

14 *Corresponding author : Géosciences Rennes UMR 6118, Université Rennes 1, CNRS, 35042

15 Rennes cedex, France. E-mail address: remi.marsac@univ-rennes1.fr (R. Marsac). 


\section{Abstract}

18 Prediction of Cerium (Ce) aqueous speciation is relevant in many research fields. Indeed, Ce

19 compounds are used for many industrial applications, which may require the control of Ce aqueous

20 chemistry for their synthesis. Aquatic geochemistry of $\mathrm{Ce}$ is also of interest. Due to growing

21 industrial use and its release to the environment, $\mathrm{Ce}$ is now considered as emerging contaminant.

22 Cerium is also used as a proxy of (paleo)redox conditions due to the $\mathrm{Ce}(\mathrm{IV}) / \mathrm{Ce}(\mathrm{III})$ redox

23 transition. Finally, $\mathrm{Ce}(\mathrm{IV})$ is often presented as a relevant analogue of tetravalent actinides

$24(\mathrm{An}(\mathrm{IV}))$. In the present study, quantum chemical calculations were conducted to highlight

25 similarities between the structure of $\mathrm{Ce}(\mathrm{IV})$ and tetravalent actinides (An(IV); An = Th, Pa, U, Np,

$26 \mathrm{Pu}$ ) aqua-ions, especially $\mathrm{Pu}(\mathrm{IV})$. Current knowledge of An(IV) hydrolysis, solubility and colloid

27 formation in water were briefly reviewed but important discrepancies observed with available data

28 for $\mathrm{Ce}(\mathrm{IV})$. Therefore, new estimation of the hydrolysis constants of Ce(IV) and solubility of

$29 \mathrm{Ce}(\mathrm{IV})-($ hydr)oxides are proposed, by analogy with $\mathrm{Pu}(\mathrm{IV})$. By plotting pH-Eh (Pourbaix)

30 diagrams, we showed that the $\mathrm{pH}$ values corresponding to the onset of $\mathrm{Ce}(\mathrm{IV})$ species formation

31 (i.e. Ce(IV)-(hydr)oxide or dissolved Ce(IV)) agreed with various experimental results. Although,

32 further experimental studies are required to obtain a more accurate thermodynamic database, the

33 present work might yet help to predict more accurately Ce chemical behavior in aqueous solution.

34 Keywords: Cerium, actinide, tetravalent, hydrolysis, solubility, speciation, aqua-ions, quantum 35 chemical calculation. 


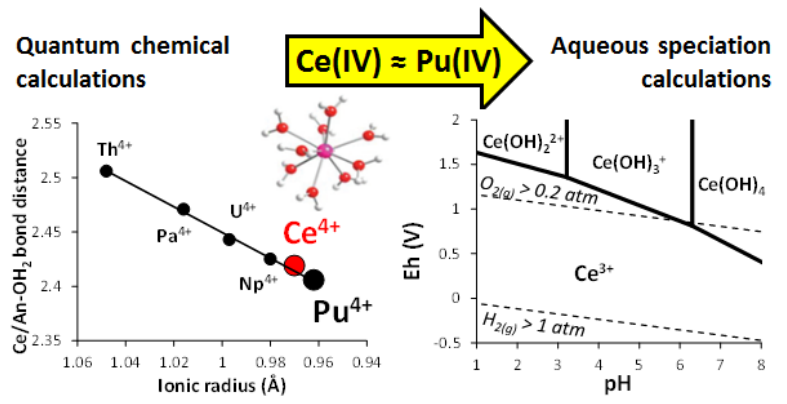
estimation of Cerium(IV) aqueous speciation using Plutonium(IV) as analogue. 


\section{Introduction}

The solution chemistry of actinide (An) ions in aquatic systems relevant for the disposal of

44 nuclear wastes is influenced by hydrolysis reactions and complexation with inorganic and organic

45 anions. ${ }^{1}$ Actinides can be found in various oxidation states in aqueous solution, which commonly

46 range from + III to + VI depending on the An (i.e., Th, U, Np, Pu). Change in oxidation state has

47 drastic consequences on An aqueous chemistry, solubility and sorption to natural organic and

48 inorganic particles and colloids, which, in turn, affect their mobility in natural systems. ${ }^{2-9}$ Only

$49 \mathrm{Th}(\mathrm{IV})$ exists in aqueous solution. $\mathrm{U}(\mathrm{IV})$ and $\mathrm{U}(\mathrm{VI})$ prevail in reducing and oxidizing conditions,

50 respectively, the stability field of $\mathrm{U}(\mathrm{V})$ (found in moderately reducing conditions) being rather

51 narrow. ${ }^{10} \mathrm{~Np}(\mathrm{IV})$ and $\mathrm{Np}(\mathrm{V})$ are the prevalent oxidation states of $\mathrm{Np}$ but $\mathrm{Np}(\mathrm{VI})$ can form in

52 oxidizing alkaline solutions. ${ }^{8,11,12} \mathrm{Pu}$ can be found in oxidation states ranging from + III to + VI in

53 environmentally relevant conditions. ${ }^{3,7,13}$ For all these An elements, the tetravalent oxidation state

54 is pertinent in near-neutral $\mathrm{pH}$ values expected to be found in nature. Because of their high electric

55 charge, tetravalent actinide ions have a strong tendency toward hydrolysis in aqueous solution and

56 undergo polynucleation or further lead to colloid formation. ${ }^{14}$ Therefore, many studies were

57 dedicated to An(IV) hydrolysis, solubility and colloids formation. ${ }^{15-19}$ The chemical behavior of

58 An(IV) was found highly consistent across the series, as commonly observed for f-elements

59 (lanthanides (Ln) (4f) and An (5f)) in the same oxidation state, and are thus often considered as

60 chemical analogues (e.g. $\left.{ }^{20-25}\right)$.

Lanthanides are naturally occurring trace elements in the environment. In contrast to its

62 lanthanide neighbors, which predominate in +III oxidation state, $\mathrm{Ce}(\mathrm{III})$ can be oxidized to $\mathrm{Ce}(\mathrm{IV})$

63 under oxidizing conditions. Preferential removal of $\mathrm{Ce}(\mathrm{IV})$ than $\mathrm{Ce}(\mathrm{III})$ from aqueous solution by

64 natural particles can lead to the development of a so-called Ce anomaly (implicitly, by comparison 
with the behavior of its lanthanide neighbors $\mathrm{La}(\mathrm{III})$ and $\mathrm{Pr}(\mathrm{III})$ ). The presence (under oxidizing

66 conditions) or the absence (under more reducing conditions) of a Ce anomaly in natural samples is

67 widely used as a proxy of (paleo)redox conditions. ${ }^{26-29}$ Since $\mathrm{Ce}$ is also used for many

68 applications, ${ }^{30-34}$ it is now considered as emerging contaminant that could affect ecosystems, due

69 to its release to the environment. ${ }^{30} \mathrm{Ce}(\mathrm{IV})$ is often presented as a relevant analogue of

$70 \mathrm{An}(\mathrm{IV}) .^{22,24,25}$ As $\mathrm{Ce}$ is not radioactive, experimental studies can be more easily conducted with

$71 \mathrm{Ce}(\mathrm{IV})$ than with An(IV), which could improve our scientific knowledge on An(IV) environmental

72 chemistry. Therefore, prediction of Ce aqueous speciation is of great interest for different research

73 fields.

However, by contrast with An(IV), there is much less information regarding Ce(IV)

75 aqueous chemistry. In fact, the present situation is such that it might be more appropriate to use

$76 \mathrm{An}(\mathrm{IV})$ to shed light on Ce(IV) aqueous chemistry than the contrary. For instance, thermodynamic

77 constants selected by Baes and $\mathrm{Mesmer}^{35}$ are often used to predict Ce(IV) hydrolysis and solubility

78 in water. This database only contains formation constants for $\mathrm{CeOH}^{3+}\left(\right.$ aq) and $\mathrm{Ce}(\mathrm{OH})_{2}{ }^{2+}{ }_{(\mathrm{aq})}$, and is

79 obviously incomplete because at least the electrically neutral $\mathrm{Ce}(\mathrm{OH})_{4(\mathrm{aq})}$ species should be in

80 equilibrium with $\mathrm{Ce}(\mathrm{IV})$-(hydr)oxides at neutral and/or alkaline $\mathrm{pH}$. Omission of such species

81 inevitably leads to drastic underestimation of Ce(IV) solubility. Hayes et al. ${ }^{36}$ used hydrolysis

82 constants of $\mathrm{Ce}(\mathrm{IV})$ more recently determined by Bilal and Müller ${ }^{37}$ to plot a $\mathrm{pH}$-Eh predominance

83 diagram. According to these results, under ambient conditions (air; $P_{\mathrm{O}_{2}}=0.2 \mathrm{~atm}$ ), Ce(IV) should

84 prevail at $\mathrm{pH}$ above $\sim 4.5$. This result contrasts with $\mathrm{Th}(\mathrm{IV})$ and lanthanide adsorption studies on

$85 \mathrm{MnO}_{2(\mathrm{~s})}$ which is known to rapidly oxidize $\mathrm{Ce}(\mathrm{III})$ to $\mathrm{Ce}(\mathrm{IV})$. Almost complete and

$86 \mathrm{pH}$-independent uptake of $\mathrm{Th}(\mathrm{IV})$ by $\mathrm{MnO}_{2(\mathrm{~s})}$ is observed for $3<\mathrm{pH}<11 .{ }^{38}$ By contrast, although

87 more efficiently removed from the solution by $\mathrm{MnO}_{2(\mathrm{~s})}$ than its lanthanide neighbors, only partial 
uptake of $\mathrm{Ce}$ (initially $+\mathrm{III}$ ) by $\mathrm{MnO}_{2(\mathrm{~s})}$ is observed under ambient air and it increases from $\mathrm{pH}=4$

89 to $\mathrm{pH}=6-7 .^{29,39}$ This suggests that, at $4<\mathrm{pH}<6-7$, although $\mathrm{Ce}(\mathrm{IV})$ is associated with the solid 90 phase (precipitated or adsorbed on $\mathrm{MnO}_{2(\mathrm{~s})}$ ), $\mathrm{Ce}(\mathrm{III})$ prevails in solution, ${ }^{40}$ as also observed in 91 previous studies dealing with $\mathrm{Pu}$ uptake by clays in moderately reducing conditions (where the $92 \mathrm{Pu}(\mathrm{IV}) / \mathrm{Pu}(\mathrm{III})$ redox couple was involved). ${ }^{41,42}$ Therefore, $\mathrm{Ce}(\mathrm{IV})$ hydrolysis constants determined 93 by Bilal and Müller ${ }^{37}$ appear to be questionable. In this study, we briefly summarized current knowledge about An(IV) aqua-ions structure, 95 hydrolysis, solubility and colloids formation in water, in the absence of complexing ligands. 96 Quantum chemical calculations were conducted to highlight similarities between the structure of $97 \mathrm{Ce}(\mathrm{IV})$ and $\mathrm{Th} / \mathrm{U} / \mathrm{Np} / \mathrm{Pu}(\mathrm{IV})$ aqua-ions. Because available hydrolysis constants and solubility data for $\mathrm{Ce}(\mathrm{IV})$ were found partly inconsistent with those of $\mathrm{Th} / \mathrm{U} / \mathrm{Np} / \mathrm{Pu}(\mathrm{IV})$, new estimated 99 thermodynamic constants for Ce(IV) were proposed.

101 Materials and methods

\section{Quantum chemical calculations}

The quantum chemical methodology used to discuss the structure and relative free energies of $\mathrm{Ce}(\mathrm{IV})$ hydrates with 10,9 and 8 water molecules $\left[\mathrm{Ce}\left(\mathrm{H}_{2} \mathrm{O}\right)_{10}\right]^{4+},\left[\mathrm{Ce}\left(\mathrm{H}_{2} \mathrm{O}\right)_{9}\right]^{4+} \cdot \mathrm{H}_{2} \mathrm{O}$, and $\left[\mathrm{Ce}\left(\mathrm{H}_{2} \mathrm{O}\right)_{8}\right]^{4+} \cdot\left(\mathrm{H}_{2} \mathrm{O}\right)_{2}$ is similar to that of our previous study on early tetravalent An species. ${ }^{43} \mathrm{~A}$ small-core relativistic effective core potential ${ }^{44}$ of the Stuttgart-Cologne group was employed for 107 the cerium atom along with the corresponding segmented basis set. ${ }^{45}$ Augmented 108 correlation-consistent polarization valence triple- $\zeta$ (aug-cc-pVTZ) basis sets were used for 109 oxygen, ${ }^{46}$ and hydrogen atoms. ${ }^{47}$ The geometries were optimized without symmetry constraints at 
110 the restricted MP2 level using the parallel resolution of the identity approximation, ${ }^{48,49}$ with the 111 appropriate atomic auxiliary basis functions. ${ }^{50,51}$ Harmonic frequency calculations were computed 112 numerically at the optimized geometry, not only to confirm that the optima found correspond to 113 energy minima, but also to compute the vibrational partition functions at $298.15 \mathrm{~K}$ and $0.1 \mathrm{MPa}$, 114 which are necessary to calculate the enthalpic and entropic contributions to the gas-phase energies.

115 The contribution of hydration to the free energies of all isomers was estimated by single-point 116 COSMO calculations with a dielectric constant of 78.9. ${ }^{52}$ To comply with the relatively low level 117 of theory (HF or DFT with small basis sets) at which the COSMO model has been parameterized, ${ }^{53}$ 118 a B3LYP based density and small def2-SVP basis sets ${ }^{54}$ on all atoms are used to compute free 119 energies of solvation. All calculations were performed with the Turbomole 7.1 quantum chemistry 120 package. ${ }^{55}$ A comparison of the nature of the cerium-water bond with that of the other tetravalent 121 actinide elements was performed using the quantum theory of atoms in molecules (QTAIM)

122 approach, implemented in the AIMAll package, ${ }^{56}$ that analyzes the appropriate wave function 123 extended files (wfx) obtained with Gaussian09. ${ }^{57}$

125 Geochemical speciation code and thermodynamic database

PHREEQC (version 2) ${ }^{58}$ is a computer code that can perform speciation and saturation-index calculations in water. PHREEQC was used to calculate species distribution plots.

128 Predominance ( $\mathrm{pH}-\mathrm{Eh})$ diagrams were obtained using PhreePlot, ${ }^{59}$ which contains an embedded 129 version of PHREEQC. The specific ion interaction theory $\left(\mathrm{SIT}^{60}\right)$ was used to extrapolate 130 thermodynamic constants at various ionic strengths. In the present work, thermodynamic constants 131 for An aqueous speciation and solubility and SIT parameters were taken from the NEA 
132 thermodynamic database ${ }^{2}$. The metastability of $\mathrm{ClO}_{4}{ }^{-}$, sometimes used as background anion, is

133 avoided in the models by defining perchlorate as a master species.

\section{Results and discussion}

\section{Tetravalent actinides and cerium aqua-ions}

136 Figure 1a plots the mean $\mathrm{An}-\mathrm{OH}_{2}$ bond distances of tetravalent actinide aqua ions determined by $137 \mathrm{~L}_{3}$-edge extended X-ray absorption fine structure (EXAFS) versus their ionic radii for coordination 138 number of eight. ${ }^{43,61}$ In a previous work, a linear relationship with a slope of about one was 139 observed for the ions from $\mathrm{Th}^{4+}$ to $\mathrm{Pu}^{4+} \cdot{ }^{43}$ Because the $\mathrm{An}-\mathrm{OH}_{2}$ bond distances for the ions up to $140 \mathrm{Pu}^{4+}$ follow closely this line, and hence the actinide contraction, it was assumed that there is no 141 major change in these ions' hydration number. To obtain detailed information on the preferred

142 coordination structure for $\mathrm{An}^{4+}$ ions in solution quantum chemical calculations were performed on 143 the decahydrates $\left[\mathrm{An}\left(\mathrm{H}_{2} \mathrm{O}\right)_{10}\right]^{4+},\left[\mathrm{An}\left(\mathrm{H}_{2} \mathrm{O}\right)_{9}\right]^{4+} \cdot \mathrm{H}_{2} \mathrm{O}$, and $\left[\mathrm{An}\left(\mathrm{H}_{2} \mathrm{O}\right)_{8}\right]^{4+} \cdot\left(\mathrm{H}_{2} \mathrm{O}\right)_{2}($ see Fig. 1b; Table

144 S1 and S2). ${ }^{43}$ Calculation of relative free energies (Table S2) showed that the nine-coordinate 145 isomer, having distorted tricapped trigonal prismatic first shell geometry, was the most stable 146 species for all ions from $\mathrm{Th}^{4+}$ to $\mathrm{Pu}^{4+}$. Although overestimated (see discussion in Vallet et al. ${ }^{62}$ ), 147 calculated $\mathrm{An}-\mathrm{OH}_{2}$ bond distances follow a linear relationship with the ionic radii, as observed by 148 EXAFS.

With an ionic radius of $0.97 \AA, \mathrm{Ce}^{4+}$ is expected to be an analogue of either $\mathrm{Np}^{4+}(0.98 \AA)$ or $150 \mathrm{Pu}^{4+}(0.96 \AA) .{ }^{61}$ Available EXAFS data somehow disagree with this hypothesis (Figure 1a), ${ }^{63}$ $151 \mathrm{Ce}^{4+}-\mathrm{OH}_{2}$ bond distance $(=2.42 \AA)$ being larger than that of $\mathrm{Np}^{4+}$ and $\mathrm{Pu}^{4+}$, but comparable to $152 \mathrm{~Pa}^{4+}-/ \mathrm{U}^{4+}-\mathrm{OH}_{2}$ bond distance (Fig. 1a; see also Table $\mathrm{S} 3$ of reference 43). In fact, standard redox 153 potential of $\mathrm{Ce}^{4+} / \mathrm{Ce}^{3+}\left(E_{\mathrm{Ce}^{4+} / \mathrm{Ce}^{3+}}\right)$ is larger than that of $\mathrm{O}_{2} / \mathrm{H}_{2} \mathrm{O},{ }^{36,37}$ hence $\mathrm{Ce}^{4+}$ is not 
154 thermodynamically stable in water at acidic $\mathrm{pH}$. As observed by Sham, ${ }^{63}$ the solution contained a 155 mixture of $\mathrm{Ce}^{4+}$ and $\mathrm{Ce}^{3+}$ and the $\mathrm{Ce}^{4+}-\mathrm{OH}_{2}$ bond distance was only estimated, hence subjected to 156 relatively large uncertainty. By contrast, present quantum chemical calculations confirm that, for 157 aqua-ions, (i) $\mathrm{Ce}^{4+}$ coordination number is 9 like in the early $\mathrm{An}^{4+}$, (ii) relative free energies for the 158 ten- and eight-coordinate isomers of $\mathrm{Ce}^{4+}$ are comparable to that of $\mathrm{Np}^{4+}$ and $\mathrm{Pu}^{4+}(\mathrm{Table} \mathrm{S} 2)$ and 159 (iii) bond distance follow $\mathrm{Np}^{4+}-\mathrm{OH}_{2}<\mathrm{Ce}^{4+}-\mathrm{OH}_{2}<\mathrm{Pu}^{4+}-\mathrm{OH}_{2}$ (Figure 1a). The topological 160 analysis of the electron charge density at the $\mathrm{Ce} / \mathrm{An}^{4+}-\mathrm{OH}_{2}$ bond critical points, presented in Table

$161 \mathrm{~S} 3$, reveal that the values of all bonding indicators, the density $\rho$, its Laplacian $\nabla^{2} \rho$, the energy 162 density $H_{\mathrm{b}}$, and the bonding index $\mathrm{D}(\mathrm{M}, \mathrm{L})$ of Ce superimpose with that of $\mathrm{Np}$ and $\mathrm{Pu}$. This further 163 supports the strong resemblance of $\mathrm{Ce}$ with $\mathrm{Np}$ and $\mathrm{Pu}$, and suggests that, as in tetravalent actinide 164 aqua ion, Ce(IV)-water bonds can be described as electrostatic. Furthermore, the difference from 165 the formal atomic valence $\mathrm{f}$ population in $\left[\mathrm{Ce}\left(\mathrm{H}_{2} \mathrm{O}\right)_{9},\left(\mathrm{H}_{2} \mathrm{O}\right)\right]^{4+}$ are very similar to that of the $\mathrm{Pu}(\mathrm{IV})$ 166 homologue. The valence d orbitals are however, slightly more populated, simply reflecting the fact 167 the $5 \mathrm{~d}$ states/orbitals are more energetically accessible in $\mathrm{Ce}(\mathrm{IV})$ than the $6 \mathrm{~d}$ ones in the heavy 168 actinide ( $\mathrm{Np}$ or $\mathrm{Pu}$ ) homologues. To stress further the similarity between $\mathrm{Ce}(\mathrm{IV})$ and $\mathrm{Pu}(\mathrm{IV})$ ions, it 169 is worthy to mention a previous theoretical study, where the objective was to find a surrogate for 170 the $\mathrm{Pu}(\mathrm{IV})$ ion in $\mathrm{HNO}_{3} / \mathrm{TBP}$ solution when it is complexed by nitrate ions, i.e $\mathrm{Pu}\left(\mathrm{NO}_{3}\right)_{6}{ }^{2-}$ and $171 \mathrm{Pu}\left(\mathrm{NO}_{3}\right)_{4}(\mathrm{TBP})_{2} \cdot{ }^{24}$ It was found that the $\mathrm{Ce}(\mathrm{IV})$ complexes have comparable behaviors in term of 172 structures, charge distribution and stabilities to those of $\mathrm{Pu}(\mathrm{IV})$, and that $\mathrm{Ce}(\mathrm{IV})$ is a priori a better 173 surrogate for $\mathrm{Pu}(\mathrm{IV})$ for experimental studies than Th(IV) or U(IV). This conclusion is in line with 174 the observed applicability of cerium dioxide $\mathrm{CeO}_{2}$ as a surrogate for plutonium dioxide $\mathrm{PuO}_{2}$ 175 steaming from their structural similarities and comparable redox behavior. ${ }^{64-67}$ 

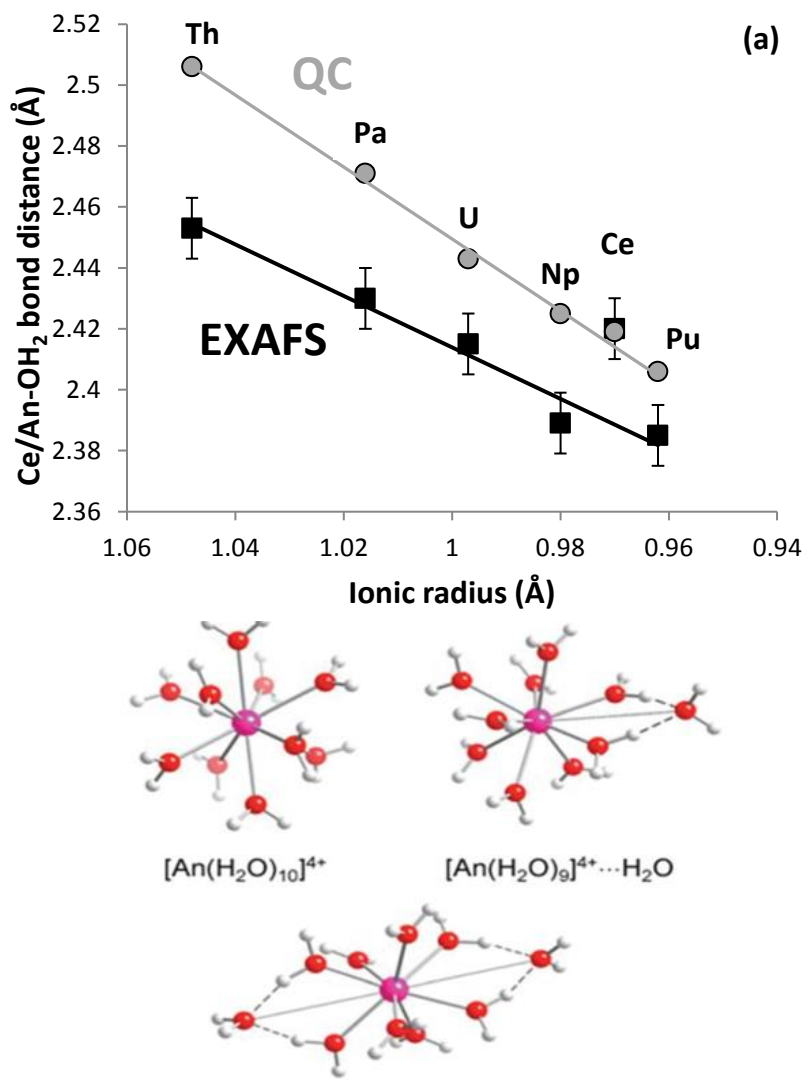

$\mathrm{H}_{2} \mathrm{O} \cdots\left[\mathrm{An}\left(\mathrm{H}_{2} \mathrm{O}\right)_{8}\right]^{4+\cdots} \mathrm{H}_{2} \mathrm{O}$

(b)

Figure 1. (a) Mean $\mathrm{An}-\mathrm{OH}_{2}$ or $\mathrm{Ce}-\mathrm{OH}_{2}$ bond distance determined by $\mathrm{L}_{3}$-edge extended $\mathrm{X}$-ray absorption fine structure (EXAFS) or by quantum chemical calculations (QC; for $\left.\left[\mathrm{An} / \mathrm{Ce}\left(\mathrm{H}_{2} \mathrm{O}\right)_{9}\right]^{4+} \cdot \mathrm{H}_{2} \mathrm{O}\right)$ versus $\mathrm{An} / \mathrm{Ce}(\mathrm{IV})$ ionic radii (b) (U)-MP2 gas-phase optimized isomeric 10-, 9-, and 8-coordinated clusters, $\left[\mathrm{An}\left(\mathrm{H}_{2} \mathrm{O}\right)_{10}\right]^{4+},\left[\mathrm{An}\left(\mathrm{H}_{2} \mathrm{O}\right)_{9}\right]^{4+} \cdot \mathrm{H}_{2} \mathrm{O}$, and $\left[\mathrm{An}\left(\mathrm{H}_{2} \mathrm{O}\right)_{8}\right]^{4+} \cdot\left(\mathrm{H}_{2} \mathrm{O}\right)_{2} \cdot{ }^{43}$ 

$\left(\mathrm{An}(\mathrm{OH})_{4(\mathrm{am})}\right.$ or $\left.\mathrm{AnO} \cdot \mathrm{xH}_{2} \mathrm{O}_{(\mathrm{am})}\right)$ and crystalline dioxides $\mathrm{AnO}_{2(\mathrm{cr})}$ globally refer to the dissolution 188 equilibrium: ${ }^{14}$

190 A relationships between $\log K_{s p}^{0}$ of $\mathrm{An}(\mathrm{OH})_{4(\mathrm{am})}$ or $\mathrm{AnO}_{2(\mathrm{cr})}$ and the ionic radii of $\mathrm{An}^{4+}$ was 191 evidenced. ${ }^{18}$ Baes and Mesmer $^{35}$ determined $\log K_{s p}^{0}$ of $\mathrm{CeO}_{2(\mathrm{cr})}$ from data given in the NBS 192 tables, ${ }^{68}$ which we find in excellent agreement with An(IV) (Figure 2a).

As previously demonstrated, the thermodynamically stable crystalline dioxides $\mathrm{AnO}_{2 \text { (cr) }}$ may be the solubility limiting solid phase at very low $\mathrm{pH}$ or elevated temperature. ${ }^{14,18,19}$ However, experimental solubility data in neutral and alkaline solutions at room temperature are 6-7 orders of magnitude higher than the low values of less than $10^{-15}$ mol $\mathrm{L}^{-1}$ calculated from the known thermodynamic data. In fact, they correspond to solubility data obtained for $\mathrm{An}(\mathrm{OH})_{4(\mathrm{am})}$. It was concluded that hydration of the surface of crystalline $\mathrm{AnO}_{2(\mathrm{cr})}$ results in an amorphous solubility 199 limiting surface layer. ${ }^{14,18}$ By analogy with An(IV), Ce(IV) solubility might be strongly 200 underestimated in near neutral to alkaline solutions when using $\log K_{s p}^{0}$ of $\mathrm{CeO}_{2 \text { (cr). }}$ It might be 201 more realistic to consider $\mathrm{Ce}(\mathrm{OH})_{4(\mathrm{am})}$ as the solubility limiting phase. 
206 Figure $2 \mathrm{~b}$ shows that experimental values of $\log [\mathrm{An}(\mathrm{IV})]_{\mathrm{aq}}$ tend to decrease with the An(IV) ionic 207 radii. When no or insufficient phase separation is applied, the measured $\mathrm{Th}(\mathrm{IV})$ and $\mathrm{Pu}(\mathrm{IV})$ 208 concentrations in the aqueous phase are generally $\sim 2.5$ orders of magnitude larger. ${ }^{15,19}$ This was 209 attributed to the formation of small An(IV) eigencolloids. Their size was estimated to be in the 210 range $1.5-2 \mathrm{~nm}$, whereas $\mathrm{An}(\mathrm{OH})_{4(\mathrm{am})}$ particles would be $2-5 \mathrm{~nm}$ large. ${ }^{15}$ Experimentally 211 determined apparent Th(IV) and $\mathrm{Pu}(\mathrm{IV})$ solubilities in neutral and alkaline solutions in presence of 212 eigencolloids $\left([\mathrm{An}(\mathrm{IV})]_{\text {coll }}\right)$ are plotted in Figure $2 \mathrm{~b}$. A similar trend is found for $\log [\mathrm{An}(\mathrm{IV})]_{\mathrm{coll}}$ 213 and $\log [\mathrm{An}(\mathrm{IV})]_{\mathrm{aq}}$ versus ionic radii. Although data are missing for $\mathrm{U}$ and $\mathrm{Np}$, this result further 214 highlights the coherence across the An(IV) series.

215 Recently, the solubility of nanocrystalline cerium dioxide $\left(\mathrm{CeO}_{2 \text { (cr,nano) }}\right)$ was determined. ${ }^{69}$ 216 At $\mathrm{pH}>6, \log [\mathrm{Ce}(\mathrm{IV})]=-7.5 \pm 0.4(1 \sigma)$ was found. This result is highly contrasting with log $217[\mathrm{An}(\mathrm{IV})]_{\mathrm{aq}}$ (Fig. 2b). However, the authors performed phase separation by ultracentrifugation 218 during $4 \mathrm{~h}$ at $4 \times 10^{4} \mathrm{~g}$. By analogy with $\mathrm{An}(\mathrm{IV})$, if we assume that $\mathrm{Ce}(\mathrm{IV})$ eigencolloids might form, 219 this set-up might be inappropriate to remove such colloids. This hypothesis is supported by the fact 220 that $\log [\mathrm{Ce}(\mathrm{IV})]$ measured by Plakhova et al. ${ }^{69}$ is in excellent agreement with $\log [\mathrm{An}(\mathrm{IV})]_{\mathrm{coll}}$ (Fig. $2212 b)$. 

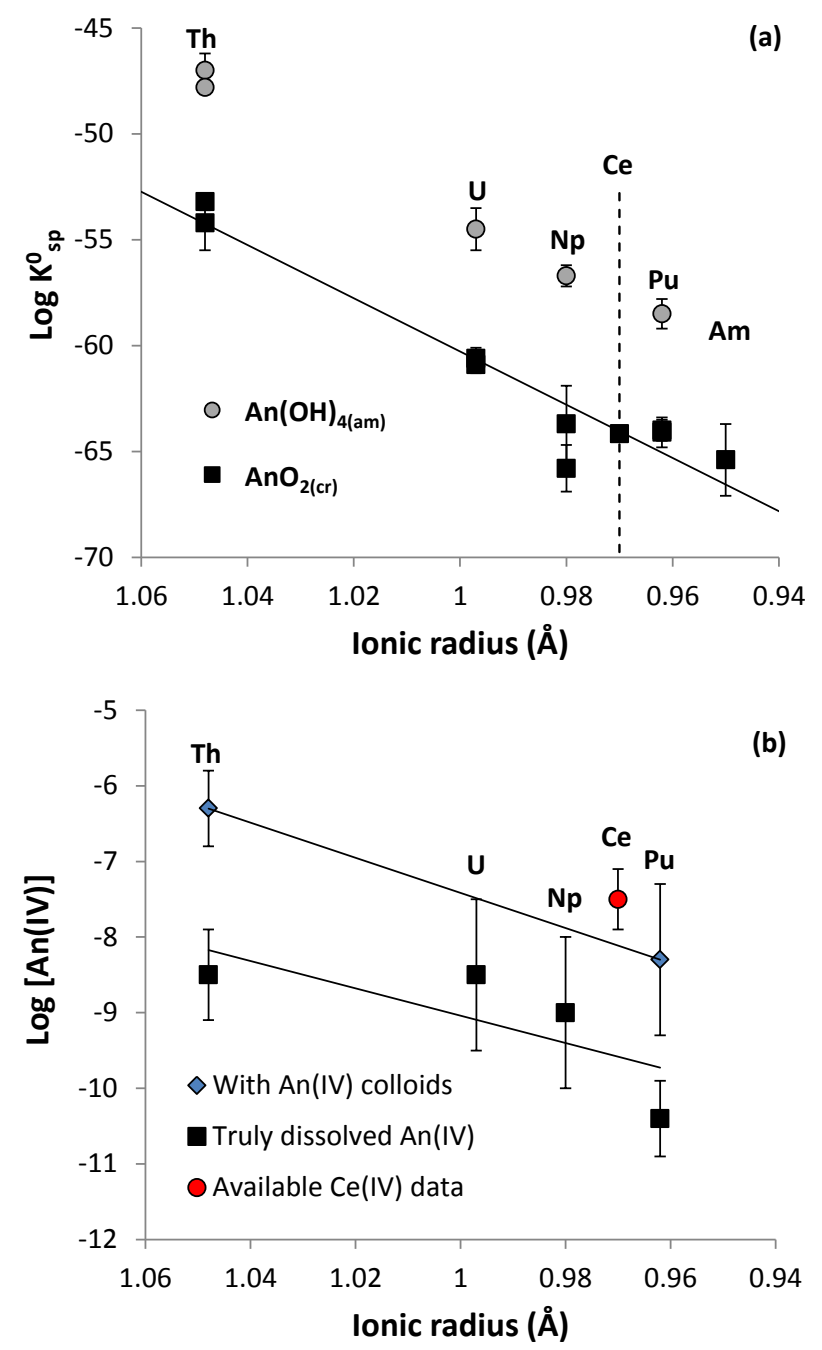

Figure 2. (a) Solubility products of $\mathrm{An}(\mathrm{OH})_{4(\mathrm{am})}$ and $\mathrm{AnO}_{2(\mathrm{cr})}$ as a function of ionic radius. ${ }^{18}$ Available data for $\mathrm{CeO}_{2(\mathrm{cr})}$ are also included. ${ }^{35}$ (b) Measured $\log$ [An(IV)] versus ionic radii at neutral to alkaline $\mathrm{pH}$ in equilibrium with $\mathrm{An}(\mathrm{OH})_{4(\mathrm{am})}$ after ultrafiltration or ultracentrifugation ("truly dissolved An(IV)") and with insufficient or without phase separation ("with An(IV) colloids"). ${ }^{14}$ Value of $\log [\mathrm{Ce}(\mathrm{IV})]$ determined by Plakhova et al. ${ }^{69}$ at $\mathrm{pH}>6$ is shown 
233 Where $\beta_{\mathrm{An}, \mathrm{n}}$ is the corresponding hydrolysis constant (at infinite dilution) and $1 \leq \mathrm{n} \leq 4$. There is no 234 evidence for the formation of $\mathrm{An}(\mathrm{OH})_{5}^{-}$(aq). As reviewed by Neck et al. ${ }^{14}$ values of $\log \beta_{\mathrm{An}, \mathrm{n}}$ are 235 consistent in the An(IV) series, and increase from Th(IV) to Pu(IV). An(IV) also tend to form 236 polynuclear species, observed for $\mathrm{pH}-[\mathrm{An}(\mathrm{IV})]$ values approaching the solubility limit of An(IV) 237 with respect to $\mathrm{An}(\mathrm{OH})_{4(\mathrm{am})}$. Polynuclear species formation can be described as follows:

$$
\mathrm{x} \mathrm{An}{ }^{4+}+\mathrm{y} \mathrm{H}_{2} \mathrm{O} \rightleftharpoons \mathrm{An}_{\mathrm{x}}(\mathrm{OH})_{\mathrm{y}}^{(4 \mathrm{x}-\mathrm{y})}+\mathrm{y} \mathrm{H}^{+} ; \quad \beta_{\mathrm{An}, \mathrm{x}, \mathrm{y}}
$$

In the case of $\mathrm{Th}(\mathrm{IV})$, dimers to hexamers $(2 \leq \mathrm{x} \leq 6)$ could be identified and corresponding 240 formation constants could be determined because of its single oxidation state in water. ${ }^{70}$ Due to its 241 complex redox chemistry, an extremely large diversity of polynuclear Pu species was observed, 242 including polymers of mixed valence states $(\mathrm{Pu}(\mathrm{IV})$ with $\mathrm{Pu}(\mathrm{III})$ or $\mathrm{Pu}(\mathrm{V})){ }^{71}{ }^{1}$ Unfortunately, 243 corresponding formation constants could not be determined. Recent studies suggested that the 244 selected hydrolysis constants of $\mathrm{Np}(\mathrm{IV})$ and $\mathrm{Pu}(\mathrm{IV})$ by the NEA might be overestimated by 245 approximately one log unit (see e.g. reference 72 and references therein) because they might 246 implicitly include polynuclear $\mathrm{Np} / \mathrm{Pu}(\mathrm{IV})$ species as well as larger $\mathrm{Np} / \mathrm{Pu}(\mathrm{IV}$ ) polymers (small 247 colloids) that are hardly removed from the solution. Nevertheless, only the selected hydrolysis 248 constants of $\mathrm{Np}(\mathrm{IV})$ and $\mathrm{Pu}(\mathrm{IV})$ by the NEA will be discussed below because recently proposed 249 sets of hydrolysis constants are incomplete and polynuclear species formation constants are 250 missing, which does not allow predicting $\mathrm{Np} / \mathrm{Pu}(\mathrm{IV})$ solubility. 

measurement in aqueous $\mathrm{HClO}_{4}$ solutions $\left([\mathrm{Ce}]_{\text {tot }}=1.25 \times 10^{-4} \mathrm{~mol} \mathrm{~L}{ }^{-1}\right)$, which are compared with that of $\mathrm{Np}(\mathrm{IV})$ and $\mathrm{Pu}(\mathrm{IV})$ in Figure 3a. Although a large diversity of polynuclear Ce (including

254

255

256

257

258

259

260

261

262

263

264

265

266

267

268

mixed $\mathrm{Ce}(\mathrm{IV})-\mathrm{Ce}(\mathrm{III}))$ species have been suggested (e.g. Ce(IV)-dimer) ${ }^{70}$, corresponding set of formation constants might be incomplete and questionable. ${ }^{35}$ Bilal and Müller ${ }^{37}$ did not account for the formation of polynuclear Ce(IV) species. Cerium(IV) hydrolysis constants might implicitly include such species and, therefore, should be somehow comparable to the selected hydrolysis constants of $\mathrm{Np}(\mathrm{IV})$ and $\mathrm{Pu}(\mathrm{IV})$ by the NEA. Values of $\log \beta_{\mathrm{Ce}, 1}$ and $\log \beta_{\mathrm{Ce}, 2}$ are quite similar to that of $\mathrm{Np}(\mathrm{IV})$ and $\mathrm{Pu}(\mathrm{IV})$, which supports the idea that these elements can be considered as analogues. However, relatively large deviation is observed for the third and a huge one for the fourth hydrolysis constants: $\beta_{\mathrm{Ce}, 3}(\approx-1.5)$ and $\beta_{\mathrm{Ce}, 4}(\approx-4.4)$ values are, respectively, 0.8 and 4.4 orders of magnitude larger on average than the corresponding constants for $\mathrm{Pu}(-2.3$ and -8.5 , respectively). Note that these differences would be larger if $\mathrm{Pu}(\mathrm{IV})$ hydrolysis constants were overestimated. $^{72}$ This result is highly contrasting with complexation data with other hard Lewis bases (e.g. $\left.\mathrm{OH}^{-}, \mathrm{F}^{-}, \mathrm{CO}_{3}{ }^{2-}, \mathrm{Cl}^{-}\right)^{73}$. For instance, formation constants of $\mathrm{AnF}^{3+}(\mathrm{aq}), \mathrm{AnF}_{2}{ }^{2+}{ }_{(\mathrm{aq})}$, $\mathrm{AnF}_{3}{ }^{+}$(aq) and $\mathrm{AnF}_{4(\mathrm{aq})}$ are comparable to those of $\mathrm{Ce}(\mathrm{IV})\left(\right.$ Fig. S1). ${ }^{74,75}$ In fact, Bilal and Müller ${ }^{37}$ determined $\log \beta_{\mathrm{Ce}, 4}$ less than $0.5 \mathrm{pH}$ unit below the onset of $\mathrm{Ce}(\mathrm{OH})_{4(\mathrm{am})}$ precipitation (determined visually). We suspect that $\log \beta_{\mathrm{Ce}, 3}$ value determined by Bilal and Müller ${ }^{37}$ might have been affected by the formation of small $\mathrm{Ce}(\mathrm{IV})$ colloids, and that $\log \beta_{\mathrm{Ce}, 4}$ very likely refers to the reaction $\mathrm{Ce}^{4+}+4 \mathrm{OH}^{-} \rightleftharpoons \mathrm{Ce}(\mathrm{OH})_{4(\mathrm{am}, \text { fresh })}$, where $\mathrm{Ce}(\mathrm{OH})_{4(\mathrm{am}, \text { fresh })}$ is a freshly precipitated amorphous (colloidal) $\mathrm{Ce}(\mathrm{IV})$ hydroxide. The consequence on $\mathrm{Ce}(\mathrm{IV})$ and $\mathrm{Pu}(\mathrm{IV})$ aqueous speciation is shown in Figure $3 b, c\left(\left[\mathrm{NaClO}_{4}\right]=0.1 \mathrm{~mol} \mathrm{~L}^{-1}\right)$. Successive $\mathrm{Ce}(\mathrm{IV})$ hydrolysis are predicted to occur within a narrow $\mathrm{pH}$-range, and $\mathrm{Ce}(\mathrm{OH})_{4(\mathrm{aq})}$ prevails at $\mathrm{pH}>3$ (Figure $3 \mathrm{~b}$ ). $\mathrm{By}$ contrast, $\mathrm{Pu}(\mathrm{OH})_{4(\mathrm{aq})}$ prevails only at $\mathrm{pH}>6$ (Figure $3 \mathrm{c}$ ). 

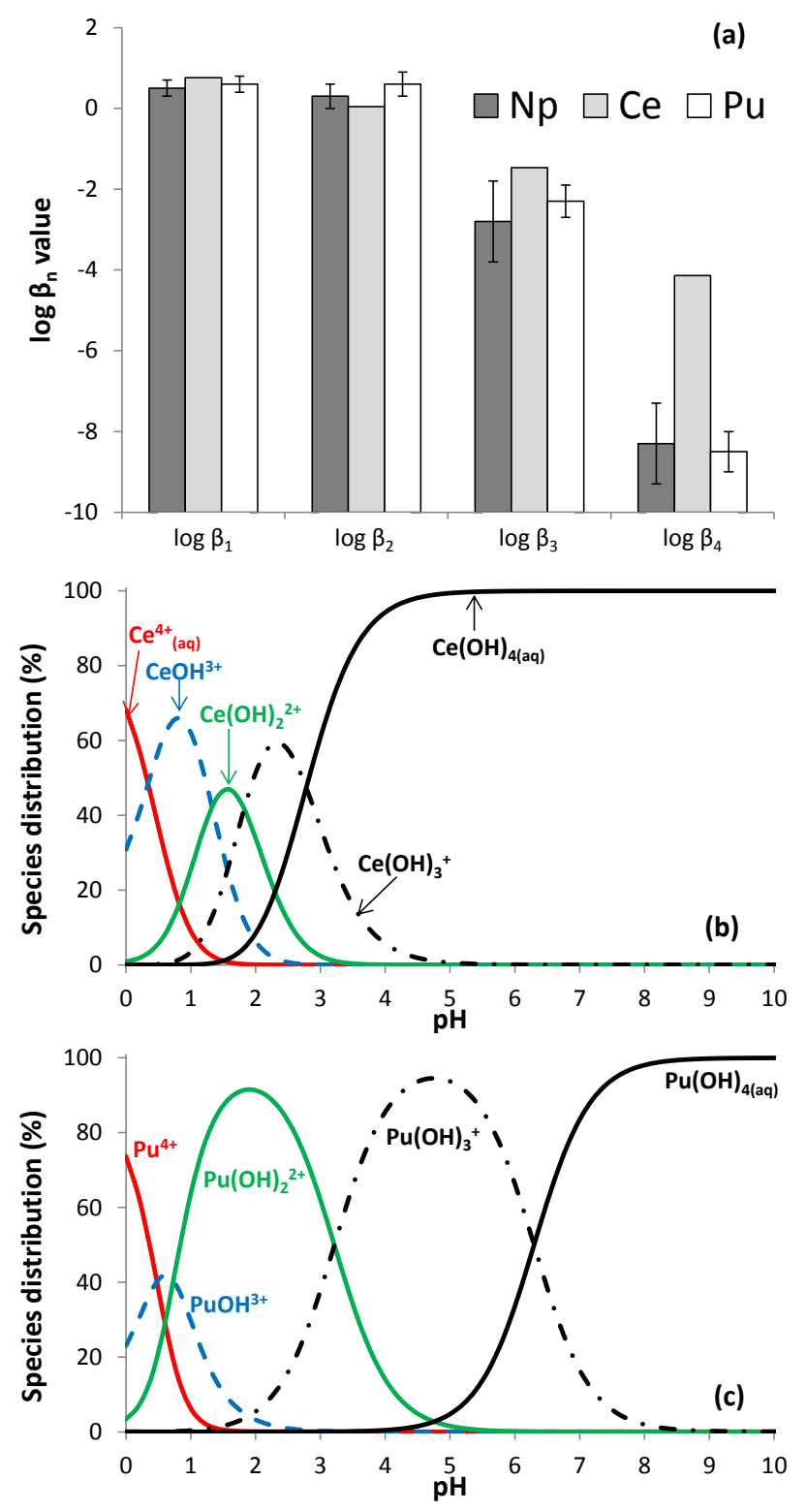

276 Figure 3. (a) Comparison between hydrolysis constants of $\mathrm{Np}(\mathrm{IV}),{ }^{2} \mathrm{Pu}(\mathrm{IV}),{ }^{2}$ and $\mathrm{Ce}(\mathrm{IV}),{ }^{37}$ Predicted speciation of (b) $\mathrm{Ce}(\mathrm{IV})$ and $(\mathrm{c}) \mathrm{Pu}(\mathrm{IV})$ versus $\mathrm{pH}\left(\left[\mathrm{NaClO}_{4}\right]=0.1 \mathrm{~mol} \mathrm{~L}^{-1}\right)$ using the hydrolysis constants given in Table $1 ., 37$

As previously observed for trivalent actinides (Am and $\mathrm{Cm}$ ) and relevant trivalent

281 lanthanide analogues $(\mathrm{Nd}$ and $\mathrm{Eu})$, the hydrolysis constants are indistinguishable within the given uncertainties. $^{20}$ The same should be observed between $\mathrm{Ce}(\mathrm{IV})$ and $\mathrm{Pu}(\mathrm{IV})$ given their similarities. 

speciation. The advantage is that, for further estimations of $\mathrm{Ce}(\mathrm{IV})$ behavior in more complex solutions (e.g. in presence of carbonates ${ }^{2}$ or natural organic matter ${ }^{76}$ ), the available database of $\mathrm{Pu}(\mathrm{IV})$ can be used for $\mathrm{Ce}(\mathrm{IV})$ without any additional corrections. Presently selected hydrolysis constants for $\mathrm{Ce}(\mathrm{III})$ and $\mathrm{Ce}(\mathrm{IV})$ are listed in Table 1. Although the $\mathrm{Pu}(\mathrm{IV})$ speciation model provided by the NEA might not be fully mechanistic (polynuclear species are missing, as discussed above $)^{72}$, it allows predicting overall $\mathrm{Pu}(\mathrm{IV})$ solubility quite accurately, ${ }^{13,15}$ which is a sufficient

292 information for the present purpose. Because the solubility data of Plakhova et al. ${ }^{69}$ at $\mathrm{pH}<6$ refer 293 to the half reaction $\mathrm{CeO}_{2 \text { (cr,nano) }}+4 \mathrm{H}^{+}+\mathrm{e}^{-} \rightleftharpoons \mathrm{Ce}^{3+}+2 \mathrm{H}_{2} \mathrm{O}$, the present estimations have no 294 consequence on the interpretations of the latter authors, as verified by speciation calculations (not 295 shown). In particular, the authors found $\log K_{s p}^{0}\left(\mathrm{CeO}_{2(\mathrm{cr}, \text { nano })}\right)=-59.3 \pm 0.3$. This value is higher 296 than for larger $\mathrm{CeO}_{2(\mathrm{cr})}$ particles, which agree with Schindler equation ${ }^{77}$ and corresponding analysis 297 of Th(IV) and $\mathrm{Pu}(\mathrm{IV})$ data. ${ }^{15}$

Table 1. Comparison between hydrolysis constants of Ce(III) and Ce(IV) used previously ${ }^{36,69}$ and in the present work 299 (p.w.).

\begin{tabular}{lcc} 
& $\log \beta^{36,69}$ & $\log \beta$ (p.w.) \\
\hline $\mathrm{Ce}^{3+}+\mathrm{H}_{2} \mathrm{O} \leftrightarrows \mathrm{CeOH}^{2+}+\mathrm{H}^{+}$ & $-8.41 \pm 0.08^{78}$ & $-8.41 \pm 0.08^{78}$ \\
$\mathrm{Ce}^{3+}+2 \mathrm{H}_{2} \mathrm{O} \leftrightarrows \mathrm{Ce}(\mathrm{OH})_{2}{ }^{+}+2 \mathrm{H}^{+}$ & $-17.60 \pm 0.24^{78}$ & $-17.60 \pm 0.24^{78}$ \\
$\mathrm{Ce}^{3+}+3 \mathrm{H}_{2} \mathrm{O} \leftrightarrows \mathrm{Ce}(\mathrm{OH})_{3(\mathrm{aq})}+3 \mathrm{H}^{+}$ & $-27.23 \pm 1.19^{78}$ & $-27.23 \pm 1.19^{78}$ \\
$\mathrm{Ce}^{4+}+\mathrm{H}_{2} \mathrm{O} \leftrightarrows \mathrm{CeOH}^{3+}+\mathrm{H}^{+}$ & $0.764^{37}$ & $0.6 \pm 0.2^{2}$ \\
$\mathrm{Ce}^{4+}+2 \mathrm{H}_{2} \mathrm{O} \leftrightarrows \mathrm{Ce}(\mathrm{OH})_{2}{ }^{2+}+2 \mathrm{H}^{+}$ & $0.048^{37}$ & $0.6 \pm 0.3^{2}$ \\
$\mathrm{Ce}^{4+}+3 \mathrm{H}_{2} \mathrm{O} \leftrightarrows \mathrm{Ce}(\mathrm{OH})_{3}{ }^{+}+3 \mathrm{H}^{+}$ & $-1.485^{37}$ & $-2.3 \pm 0.4^{2}$ \\
$\mathrm{Ce}^{4+}+4 \mathrm{H}_{2} \mathrm{O} \leftrightarrows \mathrm{Ce}(\mathrm{OH})_{4(\text { aq })}+4 \mathrm{H}^{+}$ & $-4.124^{37}$ & $-8.5 \pm 0.5^{2}$ \\
\hline
\end{tabular}



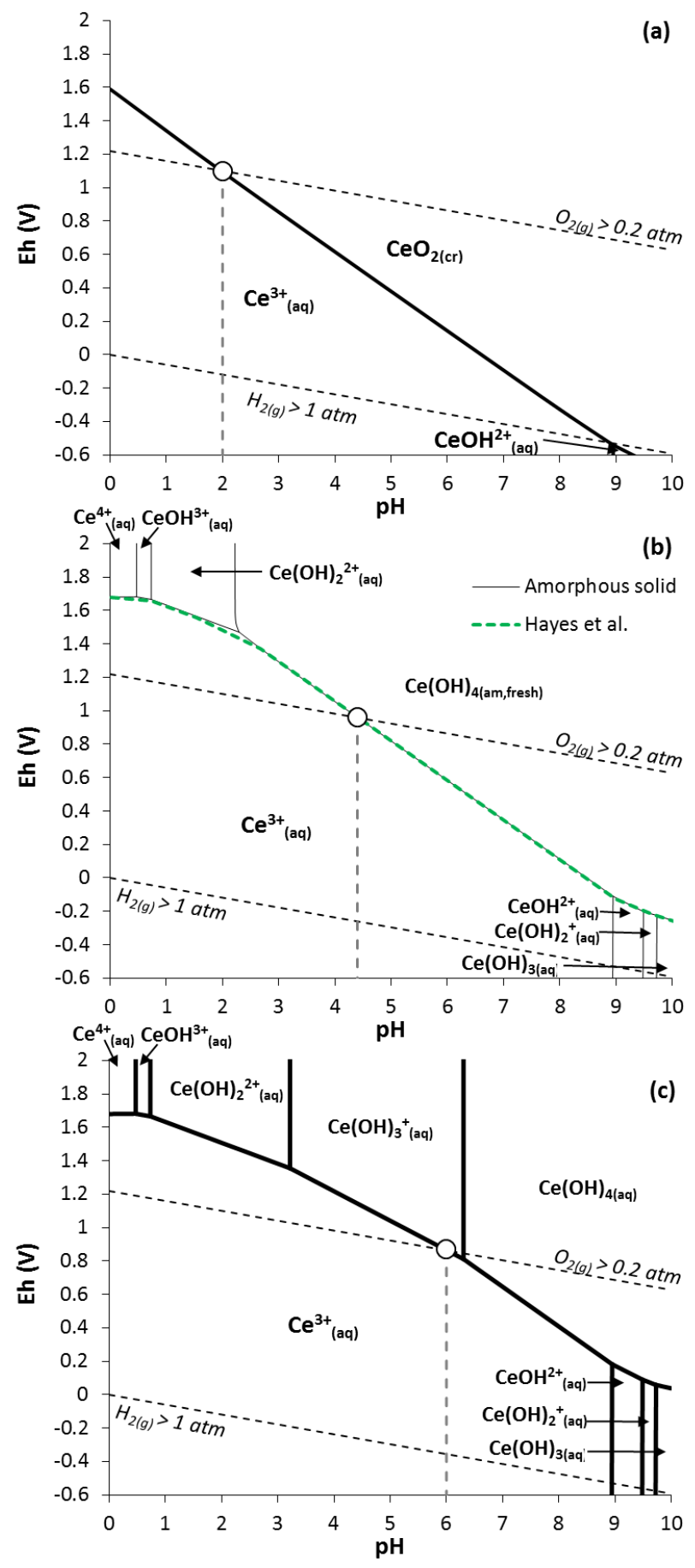

Figure 4. $\mathrm{pH}$-Eh diagrams of $\mathrm{Ce}\left([\mathrm{Ce}]=1.25 \times 10^{-4} \mathrm{~mol} \mathrm{~L}^{-1}\right.$; $\left.\left[\mathrm{NaClO}_{4}\right]=0.1 \mathrm{~mol} \mathrm{~L}^{-1}\right)$ assuming (a) formation of $\mathrm{CeO}_{2(\mathrm{cr})}$ ( $\left.\log K_{s p}^{0}=-64.16\right)$, (b) formation of $\mathrm{Ce}(\mathrm{OH})_{4(\mathrm{am}, \mathrm{fresh})}\left(\log K_{s p}^{0}=-56.8\right)$ or (c) no formation of $\mathrm{Ce}(\mathrm{IV})$-(hydr)oxide. In is shown). White circles and vertical dotted lines show the $\mathrm{pH}$ value corresponding to the $\mathrm{Ce}(\mathrm{IV}) / \mathrm{Ce}$ (III) redox 
$308\left(\left[\mathrm{NaClO}_{4}\right]=0.1 \mathrm{~mol} \mathrm{~L}{ }^{-1}\right.$; corresponding to the experimental conditions of Bilal and Müller $\left.{ }^{37}\right)$. 309 When assuming the formation of $\mathrm{CeO}_{2 \text { (cr) }}$ (Fig. 4a), for $\mathrm{P}_{\mathrm{O} 2}=0.2$ atm $\left(\mathrm{pH}+\mathrm{pe}=-\log a_{H^{+}}-\log \right.$ $\left.310 a_{e^{-}}=20.6\right), \mathrm{Ce}(\mathrm{III})$ prevails at low $\mathrm{pH}<2$ and rapidly disappears from the solution when $\mathrm{pH}$ 311 further increases (not shown; $\log [\mathrm{Ce}(\mathrm{IV})]_{\mathrm{aq}}=-16.6$ at $\mathrm{pH}>7$ according to our calculations). 312 Although redox conditions may differ from $\mathrm{pH}+\mathrm{pe}=20.6$, this result is highly contrasting with 313 previous $\mathrm{Ce}$ adsorption studies under ambient (air) conditions, where $\log [\mathrm{Ce}]_{\mathrm{aq}}>-8$ at $\mathrm{pH}=6$ in $314 \mathrm{MnO}_{2(\mathrm{~s})}$ aqueous suspensions, and where little $\mathrm{Ce}(\mathrm{III})$ oxidation to $\mathrm{Ce}(\mathrm{IV})$ by $\mathrm{Fe}(\mathrm{III})$-(hydr)oxides 315 occured. ${ }^{29}$ Hence, $\mathrm{CeO}_{2(\mathrm{cr})}$ is very likely not the solubility limiting phase in the latter study. Note 316 that the present $\mathrm{pH}$-Eh diagram (Fig. 4a) agrees very well with previous ones, ${ }^{79}$ although $\mathrm{Ce}(\mathrm{IV})$ 317 hydrolysis constants differ, because of the high stability of $\mathrm{CeO}_{2 \text { (cr). }}$.

The Ce(IV)/Ce(III) redox transition calculated by Hayes et al. ${ }^{36}$ is shown as dotted line in 319 Figure 4b. The latter authors used the hydrolysis constants reported by Bilal and Müller, ${ }^{37}$ which

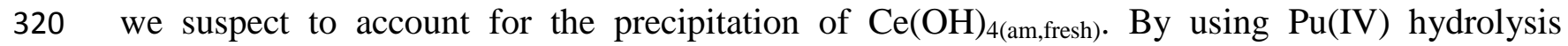
321 constants for $\mathrm{Ce}(\mathrm{IV})$, we found that both $\mathrm{pH}$-Eh diagrams coincide when $\log K_{s p}^{0} \approx-56.8$. This 322 value agrees with $\log K_{s p}^{0}=-57.6 \pm 0.7$, which could be estimated for $\mathrm{Ce}(\mathrm{OH})_{4(\mathrm{am})}$ using the 323 relationship between $\log K_{s p}^{0}$ of $\mathrm{An}(\mathrm{OH})_{4(\mathrm{am})}$ and $\mathrm{An}(\mathrm{IV})$ ionic radii (Fig. 2a). Figure 4c shows the $324 \mathrm{pH}-\mathrm{Eh}$ diagram of dissolved Ce. This diagram applies only to Ce aqueous speciation, hence 325 remaining true even when Ce precipitation and/or adsorption to another mineral occur. ${ }^{7,80}$ When $326 \mathrm{pH}+\mathrm{pe}=20.6, \mathrm{Ce}(\mathrm{III})$ prevails up to $\mathrm{pH} \approx 6$. This result is qualitatively consistent with the 327 observation that $\mathrm{Ce}(\mathrm{III})$ prevails in solution under ambient conditions in $\mathrm{MnO}_{2(\mathrm{~s})}$ aqueous 328 suspensions, while $\mathrm{Ce}(\mathrm{IV})$ is associated with the solid phase (precipitated or adsorbed onto $\left.329 \mathrm{MnO}_{2(\mathrm{~s})}\right)^{27,29,39,40}$ These results further suggest that (i) previously determined hydrolysis 
330 constants $^{37}$ were inaccurate and (ii) $\mathrm{Pu}(\mathrm{IV})$ might be a good analogue of $\mathrm{Ce}(\mathrm{IV})$.

\section{Conclusions}

In summary, we briefly reviewed most relevant mechanisms responsible for An(IV)

334 solubility in water and demonstrated the highly consistent behavior of Ce(IV) and An(IV) with 335 quantum chemical calculations, and more specifically the strong resemblance of Ce(IV) aqua ion 336 with the $\mathrm{Np}(\mathrm{IV})$ and $\mathrm{Pu}(\mathrm{IV})$ aqua ions. Because discrepancies were sometimes observed between 337 experimentally determined thermodynamic parameters of $\mathrm{Ce}(\mathrm{IV})$ and $\mathrm{An}(\mathrm{IV})$, we chose to simply 338 use the thermodynamic database of $\mathrm{Pu}(\mathrm{IV})$ to predict $\mathrm{Ce}(\mathrm{IV})$ speciation and solubility. The present 339 estimations are in good agreement with experimental studies of e.g. Ce adsorption to $\mathrm{MnO}_{2(\mathrm{~s})}$ and $340 \mathrm{Fe}(\mathrm{III})$-(hydr)oxides. However, the latter comparisons were only qualitative because of the lack of 341 experimental data on redox potentials in $\mathrm{MnO}_{2(\mathrm{~s})}$ or $\mathrm{Fe}(\mathrm{III})$-(hydr)oxides aqueous

342 suspensions. ${ }^{27,29,39}$ Although, further experimental (e.g. solubility or adsorption) studies are 343 required to verify the present assumptions and to obtain more accurate thermodynamic databases 344 for $\mathrm{Ce}(\mathrm{IV})$ and $\mathrm{An}(\mathrm{IV})$ (including mono- and polynuclear dissolved species), the present work 345 might yet help (i) to predict more accurately Ce speciation and its fate in environmental conditions 346 (ii) to use more accurately $\mathrm{Ce}$ as a proxy of (paleo)redox conditions (iii) to use $\mathrm{Ce}(\mathrm{IV}$ ) as analogue 347 for the study of An(IV) (geo)chemical behavior and (iv) to develop new cerium compounds 348 requiring the control of certain key processing factors.

\section{Acknowledgements}


This work has been partially supported by the Agence Nationale de la Recherche through the LABEX CaPPA (ANR-11-LABX-0005-01), as well as by the Ministry of Higher Education and Research, Hauts de France council and European Regional Development Fund (ERDF) through the Contrat de Projets Etat-Region (CPER CLIMIBIO).

\section{References}

1 V. Neck and J. I. Kim, Radiochim. Acta, 2000, 88, 815-822.

2 R. Guillaumont, T. Fanghänel, J. Fuger, I. Grenthe, V. Neck, D. A. Palmer and M. H. Rand, Chemical Thermodynamics, Vol. 5, Update on the Chemical Thermodynamics of Uranium, Neptunium, Plutonium, Americium and Technetium, OECD Nuclear Energy Agency, Data Bank, Elsevier, Amsterdam, 2003.

3 G. R. Choppin, J. Radioanal. Nucl. Chem., 2007, 273, 695-703.

4 H. Zänker and C. Hennig, J. Contam. Hydrol., 2014, 157, 87-105.

5 D. W. Efurd, W. Runde, J. C. Banar, D. R. Janecky, J. P. Kaszuba, P. D. Palmer, F. R. Roensch and C. D. Tait, Environ. Sci. Technol., 1998, 32, 3893-3900.

6 T. Fanghänel and V. Neck, Pure Appl. Chem., 2002, 74, 1895-1907.

7 R. Marsac, N. L. Banik, J. Lützenkirchen, R. A. Buda, J. V. Kratz and C. M. Marquardt, Chem. Geol., 2015, 400, 1-10.

8 R. Marsac, N. L. Banik, J. Lützenkirchen, C. M. Marquardt, K. Dardenne, D. Schild, J. Rothe, A. Diascorn, T. Kupcik, T. Schäfer and H. Geckeis, Geochim. Cosmochim. Acta, 2015, 152, 39-51.

9 N. L. Banik, R. Marsac, J. Lützenkirchen, C. M. Marquardt, K. Dardenne, J. Rothe, K. Bender and H. Geckeis, Geochim. Cosmochim. Acta, 2017, 215, 421-431.

10F. Huber, D. Schild, T. Vitova, J. Rothe, R. Kirsch and T. Schäfer, Geochim. Cosmochim. Acta, 2012, 96, 154-173.

11 X. Gaona, J. Tits, K. Dardenne, X. Liu, J. Rothe, M. A. Denecke, E. Wieland and M. Altmaier, Radiochim. Acta, 2012, 100, 759-770.

12 J. Tits, X. Gaona, A. Laube and E. Wieland, Radiochim. Acta, 2014, 102, 385-400.

13 V. Neck, M. Altmaier and T. Fanghänel, Comptes Rendus Chim., 2007, 10, 959-977.

14 V. Neck and J. I. Kim, Radiochim. Acta, 2001, 89, 1-16.

15 V. Neck, M. Altmaier, A. Seibert, J. I. Yun, C. M. Marquardt and T. Fanghänel, Radiochim. Acta, 2007, 95, 193-207.

16 V. Neck, R. Müller, M. Bouby, M. Altmaier, J. Rothe, M. A. Denecke and J.-I. Kim, Radiochim. Acta, 2002, 90, 485-494.

17 V. Neck, J. I. Kim, B. S. Seidel, C. M. Marquardt, K. Dardenne, M. P. Jensen and W. Hauser, Radiochim. Acta, 2001, 89, 439-446.

18 V. Neck, M. Altmaier, R. Müller, A. Bauer, T. Fanghänel and J.-I. Kim, Radiochim. Acta, 2003, 91, 253-262.

19M. Altmaier, V. Neck and T. Fanghänel, Radiochim. Acta, 2004, 92, 537-543. 
20 V. Neck, M. Altmaier, T. Rabung, J. Lützenkirchen and T. Fanghänel, Pure Appl. Chem., 2009, 81, 1555-1568.

21 A. Schnurr, R. Marsac, T. Rabung, J. Lützenkirchen and H. Geckeis, Geochim. Cosmochim. Acta, 2015, 151, 192-202.

22 Y. Suzuki, T. Nankawa, A. J. Francis and T. Ohnuki, Radiochim. Acta, 2010, 98, 397-402.

23 K. B. Krauskopf, Chem. Geol., 1986, 55, 323-335.

24M. Šulka, L. Cantrel and V. Vallet, J. Phys. Chem. A, 2014, 118, 10073-10080.

25 A. Loges, T. Wagner, M. Barth, M. Bau, S. Göb and G. Markl, Geochim. Cosmochim. Acta, 2012, 86, 296-317.

26C. R. German and H. Elderfield, Paleoceanography, 1990, 5, 823-833.

27 M. Bau, Geochim. Cosmochim. Acta, 1999, 63, 67-77.

28 O. Pourret, M. Davranche, G. Gruau and A. Dia, Chem. Geol., 2008, 251, 120-127.

29A. Ohta and I. Kawabe, Geochim. Cosmochim. Acta, 2001, 65, 695-703.

30J. T. Dahle and Y. Arai, Int. J. Environ. Res. Public. Health, 2015, 12, 1253-1278.

31 V. K. Ivanov, O. S. Polezhaeva and Y. D. Tret'yakov, Russ. J. Gen. Chem., 2010, 80, 604-617. 32 T. Montini, M. Melchionna, M. Monai and P. Fornasiero, Chem. Rev., 2016, 116, 5987-6041.

33 I. Celardo, J. Z. Pedersen, E. Traversa and L. Ghibelli, Nanoscale, 2011, 3, 1411-1420.

34D. Guyonnet, M. Planchon, A. Rollat, V. Escalon, J. Tuduri, N. Charles, S. Vaxelaire, D. Dubois and H. Fargier, J. Clean. Prod., 2015, 107, 215-228.

35C. F. Baes and R. S. Mesmer, The Hydrolysis of Cations, John Wiley \& Sons, New York, London, Sydney, Toronto., 1976.

36 S. A. Hayes, P. Yu, T. J. O'Keefe, M. J. O'Keefe and J. O. Stoffer, J. Electrochem. Soc., 2002, 149, C623-C630.

37B. A. Bilal and E. Müller, Z. Für Naturforschung A, 1992, 47, 974-984.

38L. Al-Attar and Y. Budeir, Sep. Sci. Technol., 2011, 46, 2313-2321.

39E. H. De Carlo, X.-Y. Wen and M. Irving, Aquat. Geochem., 1997, 3, 357-389.

40M. Bau and A. Koschinsky, Geochem. J., 2009, 43, 37-47.

41 N. L. Banik, R. Marsac, J. Lützenkirchen, A. Diascorn, K. Bender, C. M. Marquardt and H. Geckeis, Environ. Sci. Technol., 2016, 50, 2092-2098.

42R. Marsac, N. L. Banik, J. Lützenkirchen, A. Diascorn, K. Bender, C. M. Marquardt and H. Geckeis, J. Colloid Interface Sci., 2017, 485, 59-64.

43 N. L. Banik, V. Vallet, F. Réal, R. M. Belmecheri, B. Schimmelpfennig, J. Rothe, R. Marsac, P. Lindqvist-Reis, C. Walther, M. A. Denecke and C. M. Marquardt, Dalton Trans., 2016, 45, 453-457.

44M. Dolg, H. Stoll and H. Preuss, J. Chem. Phys., 1989, 90, 1730-1734.

45X. Cao and M. Dolg, J. Mol. Struct. THEOCHEM, 2002, 581, 139-147.

46D. E. Woon and T. H. J. Dunning, J. Chem. Phys., 1994, 100, 2975-2988.

47T. H. J. Dunning, J. Chem. Phys., 1989, 90, 1007-1023.

48C. Hättig, A. Hellweg and A. Köhn, Phys. Chem. Chem. Phys., 2006, 8, 1159-1169.

49C. Hättig, A. Hellweg and A. Köhn, J. Chem. Phys., 2000, 113, 5154-5161.

50C. Hättig, Phys. Chem. Chem. Phys., 2005, 7, 59-66.

51 F. Weigend, A. Köhn and C. Hättig, J. Chem. Phys., 2002, 116, 3175-3183.

52 A. Klamt and G. Schüürmann, J. Chem. Soc. Perkin Trans. 2, 1993, 799-805.

53 J. Ho, A. Klamt and M. L. Coote, J. Phys. Chem. A, 2010, 114, 13442-13444.

54R. Ahlrichs, M. Bär, M. Häser, H. Horn and C. Kölmel, Chem. Phys. Lett., 1989, 162, 165-169. 
55TURBOMOLE V7.1 2016, a development of University of Karlsruhe and Forschungszentrum Karlsruhe GmbH, 1989-2007, TURBOMOLE GmbH, since 2007; available from http://www.turbomole.com. 56AIMAll (Version 17.01.25), Todd A. Keith, TK Gristmill Software, Overland Park KS, USA, 2017 (aim.tkgristmill.com).

57 Gaussian 09, Revision A.02, M. J. Frisch et al, Gaussian, Inc., Wallingford CT, 2016., . 58D. L. Parkhurst and C. A. J. Appelo, User's guide to PHREEQC (Version 2) : a computer program for speciation, batch-reaction, one-dimensional transport, and inverse geochemical calculations, Water-resources Investigation Report 99-4259. USGS, Denver, Colorado, 1999. 59D. Kinniburgh and D. M. Cooper, PhreePlot, http://www.phreeplot.org. 60L. Ciavatta, Ann. Chim., 1980, 70, 551-567.

61 G. R. Choppin and E. N. Rizkalla, Handb. Phys. Chem. Rare Earths, 1994, 18, 559-590. 62 V. Vallet, P. Macak, U. Wahlgren and I. Grenthe, Theor. Chem. Acc., 2006, 115, 145-160. 63 T. K. Sham, Phys. Rev. B, 1989, 40, 6045-6051.

64 H. S. Kim, C. Y. Joung, B. H. Lee, J. Y. Oh, Y. H. Koo and P. Heimgartner, J. Nucl. Mater., 2008, 378, 98-104.

65 A. K. Tyagi, B. R. Ambekar and M. D. Mathews, J. Alloys Compd., 2002, 337, 277-281.

66 J. Gaillard, L. Venault, R. Calvet, S. Del Confetto, N. Clavier, R. Podor, M. Odorico, J.-L. Pellequer, N. Vigier and P. Moisy, J. Nucl. Mater., 2014, 444, 359-367.

67 X. Beaudoux, M. Virot, T. Chave, G. Leturcq, G. Jouan, L. Venault, P. Moisy and S. I. Nikitenko, Dalton Trans., 2016, 45, 8802-8815.

68R. H. Schumm, D. D. Wagman, S. M. Bailey, W. H. Evans and V. B. Parker, Selected values of chemical thermodynamic properties [Part 7] Tables for the Lanthanide (Rare Earth) Elements (Elements 62-76) in the standard order of arrangement, National Bureau of Standards, 1973.

69 T. V. Plakhova, A. Y. Romanchuk, S. N. Yakunin, T. Dumas, S. Demir, S. Wang, S. G. Minasian, D. K. Shuh, T. Tyliszczak, A. A. Shiryaev, A. V. Egorov, V. K. Ivanov and S. N. Kalmykov, J. Phys. Chem. C, 2016, 120, 22615-22626. 70C. Walther, M. Fuss and S. Büchner, Radiochim. Acta, 2008, 96, 411-425.

71 C. Walther, J. Rothe, B. Brendebach, M. Fuss, M. Altmaier, C. M. Marquardt, S. Büchner, H.-R. Cho, J.-I. Yun and A. Seibert, Radiochim. Acta, 2009, 97, 199-207. 72M. Altmaier, X. Gaona and T. Fanghänel, Chem. Rev., 2013, 113, 901-943. 73R. G. Pearson, J. Am. Chem. Soc., 1963, 85, 3533-3539.

74R. M. Sawant, N. K. Chaudhuri and S. K. Patil, J. Radioanal. Nucl. Chem., 1990, 143, 295-306. 75R. M. Sawant, R. K. Rastogi, M. A. Mahajan and N. K. Chaudhuri, Talanta, 1996, 43, 89-94. 76R. Marsac, N. L. Banik, C. M. Marquardt and J. V. Kratz, Geochim. Cosmochim. Acta, 2014, 131, 290-300.

77P. W. Schindler, in Equilibrium Concepts in Natural Water Systems, American Chemical Society, 1967, vol. 67, pp. 196-221.

78 J. H. Lee and R. H. Byrne, Geochim. Cosmochim. Acta, 1992, 56, 1127-1137.

79P. Yu, S. A. Hayes, T. J. O'Keefe, M. J. O'Keefe and J. O. Stoffer, J. Electrochem. Soc., 2006, 153, C74-C79.

80M. Kölling, M. Ebert and H. D. Schulz, in Redox, eds. D. J. Schüring, P. D. H. D. Schulz, P. D. W. R. Fischer, P. D. J. Böttcher and D. W. H. M. Duijnisveld, Springer Berlin Heidelberg, 2000, pp. 55-63. 